\title{
Ribavirin is not a functional mimic of the 7-methyl guanosine mRNA cap
}

\author{
YIFEI YAN, ${ }^{1}$ YURI SVITKIN, ${ }^{1}$ JOSEPH M. LEE, ${ }^{1}$ MARTIN BISAILLON, ${ }^{3}$ and JERRY PELLETIER ${ }^{1,2}$ \\ ${ }^{1}$ Department of Biochemistry and ${ }^{2}$ McGill Cancer Center, McIntyre Medical Sciences Building, McGill University, Montreal, \\ Québec H3G 1Y6, Canada \\ ${ }^{3}$ Département de Biochimie, Faculté de Médecine, Université de Sherbrooke, Sherbrooke, Québec J1H 5N4, Canada
}

\begin{abstract}
Ribavirin is a guanosine ribonucleoside analog that displays broad-spectrum anti-viral activity and is currently used for the treatment of some viral infections. Ribavirin has recently been proposed to also be a mimic of the 7-methyl guanosine cap found at the $5^{\prime}$ end of mRNAs. To obtain supporting functional data for this hypothesis, we assessed the ability of ribavirin triphosphate to interfere with the interaction between eIF4E and 7-methyl guanosine capped mRNA. In chemical cross-linking assays, cap-affinity chromatography, and cap-dependent translation assays, ribavirin was unable to function as a cap analog.
\end{abstract}

Keywords: ribavirin; cap analog; 7-methyl guanosine; translation; RTP

\section{INTRODUCTION}

Translation initiation is a highly regulated process, with ribosome recruitment being rate limiting in most instances (for review, see Gingras et al. 1999). The eIF4F complex is involved in this step and is comprised of three subunits: (1) eIF4E, the cap-binding protein responsible for binding of the complex to the mRNA 7-methyl guanosine structure in an ATP-independent fashion; (2) eIF4A, an RNA helicase required for unwinding secondary structure in preparation for $43 \mathrm{~S}$ ribosomal subunit binding; and (3) eIF4G, a modular scaffold that mediates mRNA binding of the $43 \mathrm{~S}$ preinitiation complex through interactions with eIF3. Transformation assays in cell culture (Lazaris-Karatzas et al. 1990) and studies with transgenic mice (Ruggero et al. 2004; Wendel et al. 2004) have demonstrated that eIF4E is an oncogene that contributes to cancer progression (Wendel et al. 2004). This is likely the consequence of increased protein production from mRNA species for which ribosome recruitment is highly dependent on eIF4F activity and that are involved in cellular growth and cell cycle progression (Gingras et al. 2001). These findings underscore the importance of better understanding the eIF4E/7-methyl guanosine cap interaction and of targeting eIF4E for possible therapeutic intervention.

Reprint requests to: Jerry Pelletier, McIntyre Medical Sciences Building, Room 810, 3655 Promenade Sir William Osler, McGill University, Montreal, Québec H3G 1Y6, Canada; e-mail: jerry.pelletier@mcgill.ca; fax: (514) 398-7384.

Article and publication are at http://www.rnajournal.org/cgi/doi/10.1261/ rna.2930805.
Detailed understanding of the interaction between eIF4E and the 7-methyl guanosine cap structure has been obtained from structure/activity studies utilizing cap analogs and from structural studies of eIF4E bound to cap analogs (Marcotrigiano et al. 1997; Matsuo et al. 1997). Cap analogs have been extensively utilized to study the ribosome recruitment step of translation initiation in complete translation assays (Hickey et al. 1977; Adams et al. 1978; Darzynkiewicz et al. 1987, 1989; Cai et al. 1999), in partial reactions with purified initiation factors (Sonenberg et al. 1978; Darzynkiewicz et al. 1981, 1985; Grifo et al. 1983; Tahara et al. 1983), and in direct binding assays with eIF4E (Niedzwiecka et al. 2004). There is a direct correlation between inhibition of overall translation and inhibition of eIF4F activity. There are several structure-activity relationships that have emerged from studies with cap analogs: (1) N7 alkyl and alicyclic substituents larger than ethyl decrease inhibitory activity (Adams et al. 1978; Furuichi et al. 1979; Darzynkiewicz et al. 1989); (2) aryl substitution at N7 improves the efficacy of inhibition (Cai et al. 1999); (3) replacement of the ribose by (hydroxyethoxy)methyl ether (but not by other pentoses) (Darzynkiewicz et al. 1985) or ring opening (Cai et al. 1999) decreases inhibitory activity; and (4) derivatization of the $\alpha$-phosphate moiety by $O$-methylation decreases the potency of $\mathrm{m}^{7} \mathrm{GMP}$ (Darzynkiewicz et al. 1981). In addition, there is preference for the anti-conformation in ligand binding (Darzynkiewicz et al. 1989), there is improved inhibition with increasing phosphate residues (Cai et al. 1999), and the second nucleotide residue in analogs of the form $\mathrm{m}^{7} \mathrm{GpppN}$ affects inhibitory activity in the order $\mathrm{G}>\mathrm{C}>\mathrm{U}>\mathrm{A}$ (Cai et al. 1999). The 
three-dimensional structure of eIF4E reveals a protein resembling a cupped hand with eight anti-parallel $\beta$-sheets and a narrow hydrophobic cap-binding slot on the concave surface and three $\alpha$-helices on the convex surface (Marcotrigiano et al. 1997; Matsuo et al. 1997). 7-Methyl guanine recognition is mediated by stacking between two conserved tryptophans, as well as hydrogen bonding and van der Waals contacts between the N7-methyl group and a third conserved tryptophan (Marcotrigiano et al. 1997; Matsuo et al. 1997). The stacking interaction is significantly strengthened because of charge transfer between the electron-rich indole groups and the electron-deficient 7-methyl guanine (which carries a delocalized positive charge secondary to methylation) (Ishida et al. 1988).

Ribavirin (1- $\beta$-D-ribofuranosyl-1,2,4-triazole-3-carboxamide) is a guanosine ribonucleoside analog that displays broad spectrum anti-viral activity (Sidwell et al. 1972; De Clercq 1993). In the clinic, it is used for the treatment of several viral infections, including Lassa fever virus, respiratory syncytial virus, hepatitis $C$ virus, and severe acute respiratory syndrome coronavirus (Tam et al. 2001), with low toxicity observed in animals and humans (Sidwell et al. 1972, 1979). In vivo, ribavirin is phosphorylated by cellular kinases, with ribavirin triphosphate (RTP) being the major intracellular metabolite (Miller et al. 1977; Page and Connor 1990). A number of mechanisms have been proposed to account for its anti-viral activity. Ribavirin monophosphate inhibits cellular inosine monophosphate dehydrogenase required for de novo synthesis of GTP (Streeter et al. 1973; Muller et al. 1977), and thus depletion of intracellular GTP pools would be detrimental to viral replication. Moreover, ribavirin is a substrate for viral RNA-dependent RNA polymerase, resulting in incorporation opposite cytidines and uridines into the viral genome template and leading to catastrophic lethal mutagenesis (Crotty et al. 2000, 2001; Maag et al. 2001). Ribavirin is also a substrate for viral guanylyl transferases (Goswami et al. 1979; Bougie and Bisaillon 2004) leading to the generation of viral mRNA transcripts that contain a ${ }^{5^{\prime}} \mathrm{RpppN}$ structure (where $\mathrm{R}$ is ribavirin and $\mathrm{N}$ is any nucleotide) instead of ${ }^{{ }^{\prime}} \mathrm{GpppN}$ (Bougie and Bisaillon 2004). In vitro, RpppN-terminated transcripts are not efficiently translated compared to their $\mathrm{m}^{7} \mathrm{GpppN}$-terminated counterparts (Bougie and Bisaillon 2004). This finding is at odds with the recent suggestion that ribavirin is a 7methyl guanosine cap analog (Kentsis et al. 2004). In this report, we have undertaken functional experiments assessing the ability of RTP to interfere with eIF4E/mRNA interactions or to block translation of cap-dependent translation.

\section{RESULTS}

\section{Assessing elF4E/ribavirin interactions}

To directly assess if ribavirin can function as a 7-methyl guanosine cap analog (Fig. 1A), we tested the ability of ribavirin triphosphate to inhibit cross-linking of recombi- nant eIF4E to cap-labeled oxidized mRNA (Fig. 1B). This classic assay was first used to identify eIF4E (Sonenberg and Shatkin 1977; Sonenberg et al. 1978) and consists of

$\mathbf{A}$<smiles></smiles>

B



C



D



FIGURE 1. RTP does not inhibit eIF4E/ $\mathrm{m}^{7} \mathrm{G}-\mathrm{mRNA}$ cap interaction in functional assays. (A) Chemical structures of the keto forms of 7-methyl-guanosine, guanosine, and ribavirin. $\mathrm{R}$ denotes Ribose. (B) Cross-linking of recombinant $\mathrm{His}_{6}$-eIF4E to oxidized ${ }^{32} \mathrm{P}$-labeled mRNA. Cross-linkings were performed using $1 \mu \mathrm{g}$ of eIF4E and 50,000 cpm m${ }^{7} \mathrm{G}$-labeled mRNA in the presence of $0.5 \mathrm{mM} \mathrm{m}^{7} \mathrm{GDP}$ (lane 2), $0.5 \mathrm{mM}$ GDP (lane 3), and 0.5 mM RTP (lane 4). Following digestion with $10 \mu \mathrm{g}$ RNAse A, samples were analyzed by electrophoresis on a $10 \%$ SDS/PAGE. The gel was dried and exposed to an X-OMAT film (Kodak) at $-70^{\circ} \mathrm{C}$ for $5 \mathrm{~h}$. The position of migration of recombinant His $_{6}$-eIF4E is indicated by an arrow. (C) Cross-linking of rabbit reticulocyte initiation factors (IF) to oxidized ${ }^{32} \mathrm{P}$-labeled mRNA. Crosslinkings were performed using $100 \mu \mathrm{g}$ of IFs in the absence of exogenously supplied ATP (indicated above the panel), since binding of eIF4E to the cap structure is an ATP-independent event (Sonenberg 1981). 7 methyl GDP, GDP, and RTP were used at a final concentration of 0.5 $\mathrm{mM}$ in this experiment. The position of migration of eIF4E is indicated by an arrow. (D) Affinity purification of $\mathrm{His}_{6}$-eIF4E from an $\mathrm{m}^{7} \mathrm{GDP}$ agarose matrix. Following binding of $\mathrm{His}_{6}$-eIF4E to $\mathrm{m}^{7} \mathrm{GDP}$-agarose (synthesized as previously described by Edery et al. [1988]) and extensive washing with LCB (10 mM HEPES-KOH [pH 8.0], $100 \mathrm{mM} \mathrm{KCl}, 0.2$ mM EDTA [pH 8.0]), the resin was successively incubated with 5 bed volumes $(100 \mu \mathrm{L})$ of $50 \mu \mathrm{M}$ GDP, $50 \mu \mathrm{M}$ RTP, and $50 \mu \mathrm{M} \mathrm{m}^{7} \mathrm{GDP}$. The first three $100 \mu \mathrm{L}$ of each wash were collected and $20 \mu \mathrm{L}$ processed and loaded onto a $10 \%$ SDS/PAGE. Following transfer to Immobillon P, the blot was probed with an anti-His antibody (Cell Signalling) and proteins visualized by chemiluminescence (PerkinElmer Life Sciences, Inc.). 
generating cap-labeled mRNA containing an oxidized ribose moiety that can be covalently linked to eIF4E (via Schiff base formation and subsequent reduction). Following degradation of the mRNA template with RNAse, the products are analyzed by SDS/PAGE. Proteins covalently bound to the radiolabeled cap structure are readily visualized by autoradiography (Fig. $1 \mathrm{~B}$, lane 1). Specificity in this assay is assessed using $\mathrm{m}^{7} \mathrm{GDP}$ (or $\mathrm{m}^{7} \mathrm{GTP}$ ) as a specific competitor (Fig. 1, cf. lanes 2 and 1) and GDP as a nonspecific competitor (Fig. 1, cf. lanes 3 and 1). In this assay, RTP does not interfere with the eIF4E/7methyl guanosine interaction (Fig. 1, cf. lanes 4 and 1).

As the above experiment utilized recombinant eIF4E, we repeated the cross-linking assay utilizing initiation factors prepared from rabbit reticulocyte ribosomes to assess the consequence of RTP on the cap binding properties of native eIF4E (Fig. 1C). A greater number of radiolabeled protein species are cross-linked to the cap structure when utilizing initiation factors, indicative of many proteins in the preparation binding nonspecifically (Fig. 1, lane 1). However, the interaction of one of these, eIF4E, is specifically inhibited by the presence of $\mathrm{m}^{7} \mathrm{GDP}$ in the cross-linking assay (Fig. 1, cf. lanes 2 and 1), and not by GDP (Fig. 1, cf. lanes 3 and 1). In this experiment, RTP did not impair native eIF4E's ability to interact with 7-methyl guanosine capped mRNA (Fig. 1, cf. lanes 4 and 1).

These results were confirmed in an independent assay involving elution of recombinant eIF4E from an $\mathrm{m}^{7} \mathrm{GDP}-$ agarose affinity resin (Fig. 1D). In this experiment, eIF4E was bound to $\mathrm{m}^{7} \mathrm{GDP}$ agarose and successively washed with $50 \mu \mathrm{M}$ GDP (lanes 1-3), $50 \mu \mathrm{M}$ RTP (lanes 4-6), or $50 \mu \mathrm{M} \mathrm{m}{ }^{7} \mathrm{GDP}$ (lanes 7-9). Following fractionation by SDS/ PAGE, Western blot analysis was used to identify fractions containing eluted $\mathrm{His}_{6}{ }^{-}$ eIF4E (Fig. 1D). The results indicate that, under the conditions used, GDP and RTP do not elute eIF4E from $\mathrm{m}^{7} \mathrm{GDP}$-agarose-only $\mathrm{m}^{7} \mathrm{GDP}$ is effective in this task (Fig. 1, cf. lanes 7-9 and 1-6).

\section{In vitro translation assays}

Effects on eIF4E activity by cap analogs can also be scored as inhibition of cap-dependent translation (Darzynkiewicz et al. 1987, 1989; Cai et al. 1999). We utilized translation extracts prepared from Krebs-2 ascites to determine whether RTP could inhibit cap-dependent protein synthesis (Fig. 2). Translation extracts were programmed with the bicistronic $\mathrm{FF} / \mathrm{HCV} /$ Ren mRNA (Fig. 2A), where production with GDP as well. of firefly luciferase is cap dependent and synthesis of Renilla luciferase is cap independent due to internal ribosome recruitment by the HCV IRES. In this experiment, production of firefly luciferase was inhibited by $\mathrm{m}^{7} \mathrm{GDP}$ in a dose-dependent fashion (Fig. 2B). As expected, production of Renilla in the presence of $\mathrm{m}^{7} \mathrm{GDP}$ was unaffected by concentrations up to $1 \mathrm{mM}$. In this assay, concentrations of RTP up to $1 \mathrm{mM}$ did not affect the synthesis of either firefly or Renilla luciferases (Fig. 2B). Neither GDP nor RTP affected the ratio of cap-independent to capdependent protein synthesis (Fig. 2C). However, increasing concentrations of $\mathrm{m}^{7} \mathrm{GDP}$ were associated with an increase in this ratio (Fig. 2C), consistent with the observed inhibition of $\mathrm{m}^{7} \mathrm{GDP}$ on cap-dependent protein synthesis (Fig. $2 \mathrm{~B}$ ).

\section{Assessing RTP activity}

We were concerned by the lack of activity demonstrated by RTP (from Moravek Biochemicals) in these assays, despite having compounds of high purity (see Materials and
A

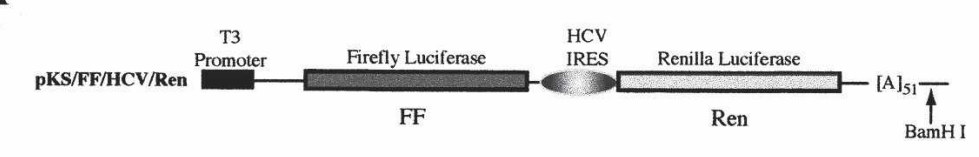

B

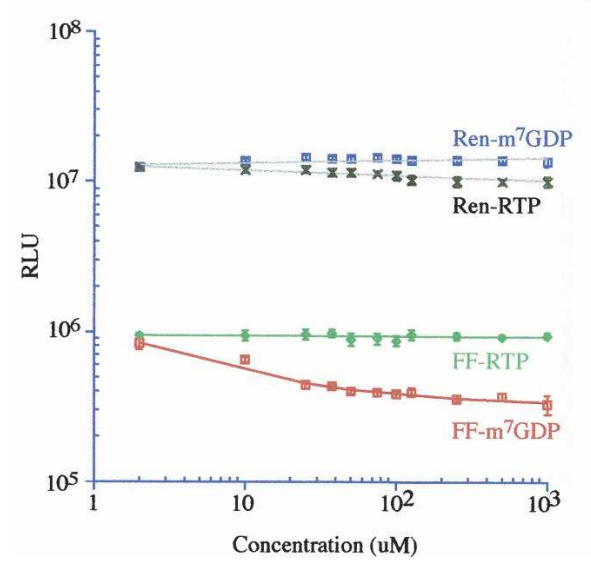

C

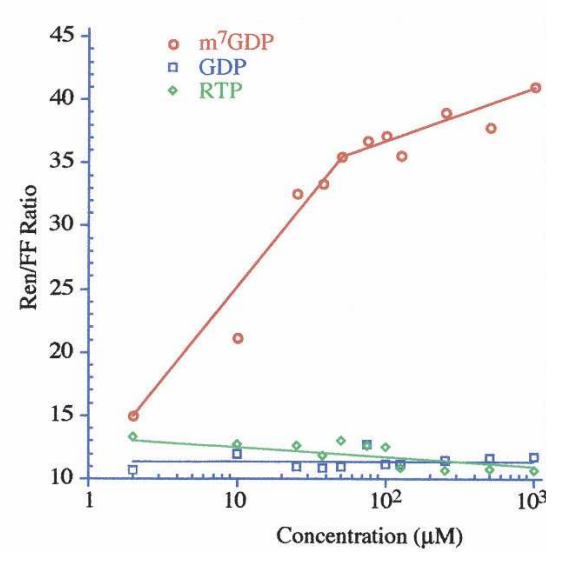

FIGURE 2. In vitro translations in the presence of RTP, $m^{7}$ GDP, and GDP. (A) Schematic diagram of the $\mathrm{pKS} / \mathrm{FF} / \mathrm{HCV} /$ Ren bicistronic construct. To generate mRNA for in vitro transcriptions, the plasmid was linearized within the $3^{\prime}$ UTR with BamHI. The firefly luciferase coding region is denoted by a blackened box and the Renilla coding region is denoted by a light gray box. The HCV IRES allows for internal initiation and cap-independent translation of the downstream Renilla cistron. (B) Dose response curve illustrating the effect of RTP and $\mathrm{m}^{7} \mathrm{GDP}$ on translation of FF/HCV/Ren in Krebs extracts. Translations were performed in the presence of the indicated amounts of RTP or $\mathrm{m}^{7} \mathrm{GDP}$ and at a final mRNA and $\mathrm{K}^{+}$concentration of $5 \mu \mathrm{g} / \mathrm{mL}$ and $100 \mathrm{mM}$, respectively. Control translation reactions contained equivalent amounts of vehicle. The obtained luciferase activities for each different mRNA were normalized to the activity obtained in the control translations of the same mRNA species (which was set at one) and plotted as a function of compound concentration. Each data point represents the average of eight independent translations and the standard error of the mean is shown (too small to be seen for many of the data points). Log scale is used on both axes. $(C)$ The relative ratios of Renilla/firefly luciferase values were taken from $B$ and are plotted for each compound as a function of concentration. Included in this panel are the results from a titration performed 
Methods). Therefore the cross-linking assay (Fig. 1B) and in vitro translation assays (Fig. 2) were performed with a different RTP preparation (Jena Biosciences) and yielded the same results (data not shown). Nonetheless, we also used two independent functional assays to ensure that our RTP preparations were active. First, during the capping process, vaccinia virus guanylyltransferase forms a GMPenzyme intermediate that can be inhibited by RTP (Bougie and Bisaillon 2004). Using $\alpha-{ }^{32} \mathrm{P}-\mathrm{GTP}$, and resolving the enzyme intermediate by SDS/PAGE, our RTP preparations inhibited this reaction by $\sim 35 \%$. This response is dose dependent and similar to previously reported concentrations required to achieve inhibition of this reaction (Bougie and Bisaillon 2004; Fig. 3A). Second, an in vitro replication system for EMC virus has recently been described (Svitkin and Sonenberg 2003) that can be used to score for the

$\mathbf{A}$

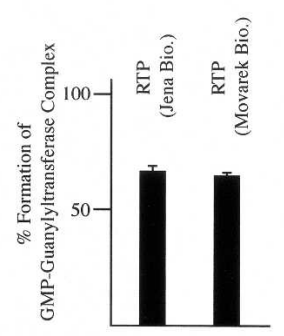

B

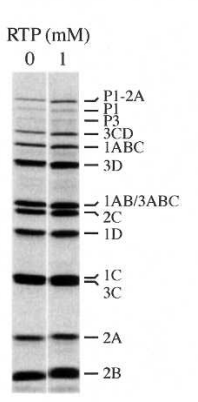

C

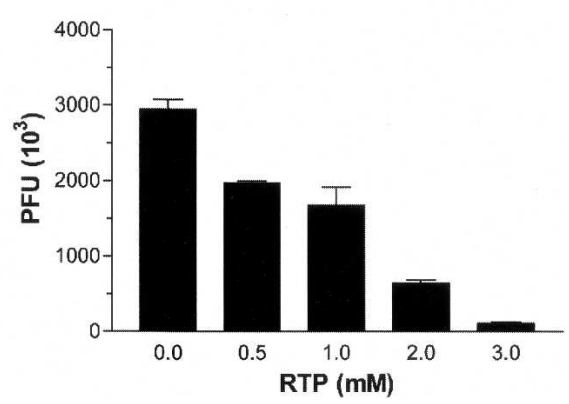

FIGURE 3. RTP inhibits Vaccinia virus guanylyltransferase activity and in vitro EMCV production. $(A)$ Inhibition of guanylytransferaseGMP complex formation by RTP. Recombinant guanylytransferase was incubated with $\alpha-\left[{ }^{32} \mathrm{P}\right] \mathrm{GTP}$ and the extent of guanylytransferaseGMP complex monitored as previously described (Bougie and Bisaillon 2004). The extent of nucleotidyl-enzyme formation in the presence of $2 \mathrm{mM}$ RTP, relative to reactions lacking RTP, is shown. (B) RTP does not affect EMCV protein synthesis. Cell-free synthesis of EMCV was performed in the presence of RTP, as previously described (Svitkin and Sonenberg 2003). EMCV RNA $(20 \mu \mathrm{g} / \mathrm{mL}$ ) was translated in the presence of $\left[{ }^{35} \mathrm{~S}\right]$ methionine. After $1 \mathrm{~h}, 5-\mu \mathrm{L}$ aliquots were withdrawn, supplemented with SDS sample buffer, and subjected to SDS-15\% PAGE. An autoradiogram of the dried gel is shown, with the assignment of the polypeptides shown. (C) RTP inhibits in vitro cell-free synthesis of EMCV. Krebs-2 S10 extracts were incubated for $20 \mathrm{~h}$ at $32^{\circ} \mathrm{C}$ in the presence of EMCV RNA (20 $\mu \mathrm{g} / \mathrm{mL}$ ) containing the indicated concentrations of RTP. Samples were treated with a mixture of RNase A and T1, serially diluted, and plaque assays carried out on confluent BHK-21 cells. Indicated are the plaque forming units (PFU) obtained. Plaque assays were performed in duplicate and the error of the mean is shown. mutagenic properties of RTP, since incorporation of RTP into newly replicated EMCV strands is expected to reduce viral fitness (Crotty et al. 2000; Maag et al. 2001). Using this system, EMCV RNA-programmed Krebs extracts were incubated in the presence or absence of RTP. As expected, RTP had no effect on the efficiency or spectrum of viral proteins produced in vitro, indicating that it does not exert nonspecific inhibition on translation of the viral template in this assay (Fig. 3B). However, a dose-dependent reduction in the production of infectious virus was noted when RTP was present in the cell-free synthesis reaction (Fig. 3C). Taken together, these results indicate that our RTP preparations are biologically active.

\section{DISCUSSION}

In the current study, we used several assays to assess whether the eIF4E/7-methyl guanosine cap interaction could be inhibited by ribavirin triphosphate (Kentsis et al. 2004). Ribavirin triphosphate does not prevent recombinant or native eIF4E from interacting with capped mRNA (Fig. 1B,C) and is incapable of eluting eIF4E from a $\mathrm{m}^{7} \mathrm{GDP}$-affinity matrix (Fig. 1D). Whereas $\mathrm{m}^{7} \mathrm{GDP}$ inhibited cap-dependent protein synthesis, RTP and GDP were not active in this assay (Fig. 2). Consistent with this finding is a report that ribavirin-capped mRNAs (RpppN-terminated) translate much less efficiently than their capped, methylated counterparts $\left(\mathrm{m}^{7} \mathrm{GpppN}\right.$-terminated) (Bougie and Bisaillon 2004).

Our results are different from those reported by Kentsis et al. (2004), although we do not fully understand the reasons. Some of the discrepancies may be a consequence of experimental design or off-target effects of RTP on cellular processes. Additionally, nucleotides may bind to many proteins nonspecifically, as exemplified by the cross-linking assay in Figure 1C. Although several proteins are observed to bind to radiolabeled cap structure in this assay, only the interaction of eIF4E is specific. Hence, experiments assessing nucleotide interaction with eIF4E need to use $\mathrm{m}^{7} \mathrm{GDP}$ (or $\mathrm{m}^{7} \mathrm{GTP}$ ) as specific competitors to ensure that the observed interactions are mediated through the cap binding site of eIF4E and not due to allosteric effects. As well, nonspecific disruption of protein-RNA interactions by nucleotides have been previously reported (Sonenberg and Shatkin 1978).

Ribavirin has been reported to exert anti-cancer activity in a murine model using $\mathrm{FaDu}$ hypopharyngeal squamous cells treated for $20 \mathrm{~d}$ at $40 \mu \mathrm{g} / \mathrm{kg} / \mathrm{day}$ (Kentsis et al. 2004). This model system is dependent on overexpression of eIF4E for its tumorigenicity, as reduction of eIF4E expression results in suppression of tumor growth. Kentsis et al. (2004) correlated the chemotherapeutic effect of ribavirin to inhibition of eIF4E activity. Our results suggest that the mechanism of action is unlikely to be the consequence of perturbing eIF4E/7-methyl guanosine cap interaction. The efficacy of 
ribavirin seen on $\mathrm{FaDu}$ hypopharyngeal squamous tumors may be related to its effects on nucleo-cytoplasmic shuttling and/or to the transport of cyclin D1 (Kentsis et al. 2004).

We note that the NCI Developmental Therapeutics Program has reported evaluation of ribavirin in several murine cancer models, including B16 melanoma, CX-1 adenocarcinoma, colon carcinoma, mammary adenocarcinoma, ependymoblastoma, L1210 and P388 leukemias, and Lewis and Madison 109 lung carcinoma (http://dtp.nci.nih.gov/ dtpstandard/servlet/dwindex?searchtype=namestarts $\&$ chemnameboolean=and\&outputformat $=$ html\&searchlist $=$ ribavirin\%0D\%0A\&Submit=Submit). From over 100 different experiments in mice where the majority of animals survived to the anti-tumor endpoint, and using a variety of treatment schedules with ribavirin doses as high as $900 \mathrm{mg} /$ $\mathrm{kg} /$ injection, only two experiments showed anti-tumor activity. Treatment of one cohort of mice with colon carcinoma (implanted subcutaneous) at $50 \mathrm{mg} / \mathrm{kg} /$ injection and another cohort with mammary adenocarcinomas CD8F1 (implanted subcutaneous) at $25 \mathrm{mg} / \mathrm{kg} /$ injection showed a $\% \mathrm{~T} / \mathrm{C}$ (treatment/control survival ratio) of 159 and 288, respectively. However, these data were not reproduced at higher dose escalation or upon repetition of the experiments. Although the NIH program did not test FaDu hypopharyngeal squamous cells, their data suggest that, under the conditions tested and on the tumors assayed, ribavirin is not a general anti-cancer agent.

\section{MATERIALS AND METHODS}

\section{Reagents and general methods}

Restriction endonucleases and T3 RNA polymerase were purchased from New England Biolabs. $5-{ }^{3} \mathrm{H}$-cytidine triphosphate $(20.5 \mathrm{Ci} /$ $\mathrm{mmol}), \quad \alpha-\left[{ }^{32} \mathrm{P}\right] \mathrm{GTP}(>3000 \mathrm{Ci} / \mathrm{mmol}), \quad$ and $\left[{ }^{35} \mathrm{~S}\right]$ methionine $(>1000 \mathrm{Ci} / \mathrm{mmol})$ were obtained from Perkin Elmer Life Sciences. Preparation of plasmid DNA, restriction enzyme digestion, and agarose gel electrophoresis of DNA were carried out using standard methods (Sambrook and Russell 2001). $\mathrm{m}^{7}$ GDP and GDP were purchased from Sigma. RTP was obtained from two independent sources: One was custom synthesized by Moravek Biochemicals, Inc., and the other was obtained from Jena Biosciences. Compound purity was independently assessed through LC-MS and established to be $96.5 \%$ ( $\left.\mathrm{m}^{7} \mathrm{GDP}\right), 88.7 \%$ (GDP), and 100\% (RTP; Movarek Biochemicals, Inc.). RTP from Jena Biosciences was quality-controlled by the manufacturer and assessed to be $>95 \%$ pure by LC-MS.

\section{Purification of recombinant $\mathrm{His}_{6}$-elF4E}

Recombinant $\mathrm{His}_{6}$-eIF4E was expressed from pProEx-4E transformed into BL21DE3/pLysS, grown in Terrific Broth/Amp at $37^{\circ} \mathrm{C}$ until $\mathrm{OD}_{600} \sim 0.7$, and induced with IPTG $(0.25 \mathrm{mM}$ final). Cells were grown for a further $4 \mathrm{~h}$ at $37^{\circ} \mathrm{C}$ prior to harvest. Bacteria cultures were centrifuged $10 \mathrm{~min}$ at $5000 \mathrm{rpm}$ in a RC3B centrifuge and the bacterial pellets were resuspended in Buffer A (50 mM HEPES-KOH [pH 7.5], $500 \mathrm{mM} \mathrm{KCl,} \mathrm{5mM} \mathrm{DTT,} \mathrm{1 \%}$
Triton X-100, $1 \mu \mathrm{g} / \mathrm{mL}$ aprotinin, $1 \mu \mathrm{g} / \mathrm{mL}$ leupeptin, $1 \mu \mathrm{g} / \mathrm{mL}$ pepstatin, $1 \mathrm{mM}$ PMSF). The suspended cells were sonicated on ice $(8 \times 30 \mathrm{sec})$, followed by treatment with DNase I $(20 \mathrm{mg} / \mathrm{L})$ and RNase $\mathrm{A}(5 \mathrm{mg} / \mathrm{L})$ at $30^{\circ} \mathrm{C}$ for $20 \mathrm{~min}$. Inclusion bodies were sedimented by centrifugation at $\sim 32,000 \mathrm{~g}(18,000 \mathrm{rpm}$ in a RC5B/ SS34 rotor) for $45 \mathrm{~min}$. The pellets were washed twice in TBS/Tx (25 mM Tris- $\mathrm{HCl}[\mathrm{pH}$ 7.2], $137 \mathrm{mM} \mathrm{NaCl}, 3 \mathrm{mM} \mathrm{KCl,} 1 \%$ Triton $\mathrm{X}-100)$ with centrifugation steps of $32,000 \mathrm{~g}$ between washes.

The final pellets were solubilized in $50 \mathrm{mM}$ HEPES-KOH $(\mathrm{pH}$ 7.5), $100 \mathrm{mM} \mathrm{KCl}, 25 \mathrm{mM}$ DTT, and $6 \mathrm{M}$ guanidine- $\mathrm{HCl}$ at $4^{\circ} \mathrm{C}$. Insoluble material was removed by ultracentrifugation at $100,000 \mathrm{~g}$ for $30 \mathrm{~min}$ and followed by determination of protein concentration. The protein was diluted in the above buffer to $\sim 1-2 \mathrm{mg} / \mathrm{mL}$ and stepwise dialysis performed over a period of $2 \mathrm{~d}$ to renature His $_{6}$-eIF4E (in the above-mentioned HEPES buffer containing $6 \mathrm{M}, 4 \mathrm{M}, 2 \mathrm{M}$, and $1 \mathrm{M}$ guanidine- $\mathrm{HCl}$ ). $\mathrm{His}_{6}$-eIF4E protein was then diluted to $>0.5 \mathrm{mg} / \mathrm{mL}$ and dialysis continued against guanidine- $\mathrm{HCl}$ concentrations of $500 \mathrm{mM}, 250 \mathrm{mM}$, and $125 \mathrm{mM}$. A final dialysis was performed against LCB $(20 \mathrm{mM}$ HEPES-KOH [pH 7.5], $100 \mathrm{mM} \mathrm{KCl,} 0.1 \mathrm{mM}$ EDTA, $0.1 \mathrm{mM} \mathrm{EGTA)} \mathrm{and}$ insoluble material separated by centrifugation and filtration through a $0.45 \mu \mathrm{m}$ filter (Millipore). The filtrate was then purified by $\mathrm{m}^{7} \mathrm{GDP}$-agarose affinity chromatography, as previously described (Edery et al. 1995).

\section{Cross-linking assays to oxidized mRNA cap structures}

In vitro transcribed mRNA was capped and methylated with $\alpha-{ }^{32} \mathrm{P}-$ GTP and SAM (S-adenosyl methionine) using vaccinia guanylyltransferase, as previously described (Pelletier and Sonenberg 1985). The $5^{\prime}$ and $3^{\prime}$ end ribose moieties were oxidized to dialdehydes using sodium periodate (Sonenberg and Shatkin 1977). Cross-linking reactions with recombinant $\mathrm{His}_{6}$-eIF4E and initiation factors were performed and analyzed as described (Sonenberg and Shatkin 1977).

\section{In vitro translation assays}

In vitro transcriptions were performed using BamHI-linearized pKS/FF/HCV/Ren DNA template (Fig. 2A) in Krebs extracts at a final mRNA concentration of $5 \mu \mathrm{g} / \mathrm{mL}$ (Novac et al. 2004; Svitkin and Sonenberg 2004). Firefly and Renilla luciferase activity (RLU) were measured on a Berthold Lumat LB 9507 luminometer (Dyer et al. 2000).

\section{Guanylyltransferase assay}

The RNA guanylyltransferase assay was performed with the vaccinia virus D1 protein that had been expressed and purified as described previously (Bougie and Bisaillon 2004). Briefly, $2 \mu \mathrm{g}$ of the enzyme were incubated with $10 \mu \mathrm{M}\left[\alpha-{ }^{32} \mathrm{P}\right] \mathrm{GTP}$ in a buffer containing $50 \mathrm{mM}$ Tris- $\mathrm{HCl}(\mathrm{pH} 8.0), 5 \mathrm{mM} \mathrm{DTT}$, and $5 \mathrm{mM}$ $\mathrm{MgCl}_{2}$ for $5 \mathrm{~min}$ at $37^{\circ} \mathrm{C}$. The reactions were stopped by the addition of EDTA to $10 \mathrm{mM}$ and SDS to $1 \%$. Reactions were analyzed by electrophoresis through a $12.5 \%$ polyacrylamide gel containing $0.1 \%$ SDS and the radiolabeled proteins were visualized by autoradiography of the gel. The extent of covalent complex formation was quantitated by scanning the gel with a PhosphorImager (Molecular Dynamics). 


\section{ACKNOWLEDGMENTS}

We are grateful to Jany Lapointe for experimental expertise during the course of this work. This work was supported by an NCIC grant (no. 014313) to J.P. M.B. is a New Investigator Scholar from the Canadian Institute of Health Research (CIHR). J.P. is a Canadian Institute of Health Research (CIHR) Senior Investigator.

Received April 26, 2005; accepted May 19, 2005.

\section{REFERENCES}

Adams, B.L., Morgan, M., Muthukrishnan, S., Hecht, S.M., and Shatkin, A.J. 1978. The effect of "cap" analogs on reovirus mRNA binding to wheat germ ribosomes. Evidence for enhancement of ribosomal binding via a preferred cap conformation. J. Biol. Chem. 253: 2589-2595.

Bougie, I. and Bisaillon, M. 2004. The broad spectrum antiviral nucleoside ribavirin as a substrate for a viral RNA capping enzyme. J. Biol. Chem. 279: 22124-22130.

Cai, A., Jankowska-Anyszka, M., Centers, A., Chlebicka, L., Stepinski, J., Stolarski, R., Darzynkiewicz, E., and Rhoads, R.E. 1999. Quantitative assessment of mRNA cap analogues as inhibitors of in vitro translation. Biochemistry 38: 8538-8547.

Crotty, S., Maag, D., Arnold, J.J., Zhong, W., Lau, J.Y., Hong, Z., Andino, R., and Cameron, C.E. 2000. The broad-spectrum antiviral ribonucleoside ribavirin is an RNA virus mutagen. Nat. Med. 6: 1375-1379.

Crotty, S., Cameron, C.E., and Andino, R. 2001. RNA virus error catastrophe: Direct molecular test by using ribavirin. Proc. Natl. Acad. Sci. 98: 6895-6900.

Darzynkiewicz, E., Antosiewicz, J., Ekiel, I., Morgan, M.A., Tahara, S.M., and Shatkin, A.J. 1981. Methyl esterification of $\mathrm{m7G5}$ 'p reversibly blocks its activity as an analog of eukaryotic mRNA 5'-caps. J. Mol. Biol. 153: 451-458.

Darzynkiewicz, E., Ekiel, I., Tahara, S.M., Seliger, L.S., and Shatkin, A.J. 1985. Chemical synthesis and characterization of 7-methylguanosine cap analogues. Biochemistry 24: 1701-1707.

Darzynkiewicz, E., Ekiel, I., Lassota, P., and Tahara, S.M. 1987. Inhibition of eukaryotic translation by analogues of messenger RNA $5^{\prime}$-cap: Chemical and biological consequences of $5^{\prime}$-phosphate modifications of 7-methylguanosine $5^{\prime}$-monophosphate. Biochemistry 26: $4372-4380$.

Darzynkiewicz, E., Stepinski, J., Ekiel, I., Goyer, C., Sonenberg, N., Temeriusz, A., Jin, Y., Sijuwade, T., Haber, D., and Tahara, S.M. 1989. Inhibition of eukaryotic translation by nucleoside $5^{\prime}$-monophosphate analogues of mRNA $5^{\prime}$-cap: changes in N7 substituent affect analogue activity. Biochemistry 28: 4771-4778.

De Clercq, E. 1993. Antiviral agents: Characteristic activity spectrum depending on the molecular target with which they interact. Adv. Virus Res. 42: 1-55.

Dyer, B.W., Ferrer, F.A., Klinedinst, D.K., and Rodriguez, R. 2000. A noncommercial dual luciferase enzyme assay system for reporter gene analysis. Anal. Biochem. 282: 158-161.

Edery, I., Altmann, M., and Sonenberg, N. 1988. High-level synthesis in Escherichia coli of functional cap-binding eukaryotic initiation factor eIF-4E and affinity purification using a simplified capanalog resin. Gene 74: 517-525.

Edery, I., Chu, L.L., Sonenberg, N., and Pelletier, J. 1995. An efficient strategy to isolate full-length cDNAs based on an mRNA cap retention procedure (CAPture). Mol. Cell. Biol. 15: 3363-3371.

Furuichi, Y., Morgan, M.A., and Shatkin, A.J. 1979. Synthesis and translation of mRNA containing $5^{\prime}$-terminal 7-ethylguanosine cap. J. Biol. Chem. 254: 6732-6738.

Gingras, A.C., Raught, B., and Sonenberg, N. 1999. eIF4 initiation factors: Effectors of mRNA recruitment to ribosomes and regulators of translation. Annu. Rev. Biochem. 68: 913-963.

. 2001. Regulation of translation initiation by FRAP/mTOR. Genes \& Dev. 15: 807-826.
Goswami, B.B., Borek, E., Sharma, O.K., Fujitaki, J., and Smith, R.A. 1979. The broad spectrum antiviral agent ribavirin inhibits capping of mRNA. Biochem. Biophys. Res. Commun. 89: 830-836.

Grifo, J.A., Tahara, S.M., Morgan, M.A., Shatkin, A.J., and Merrick, W.C. 1983. New initiation factor activity required for globin mRNA translation. J. Biol. Chem. 258: 5804-5810.

Hickey, E.D., Weber, L.A., Baglioni, C., Kim, C.H., and Sarma, R.H. 1977. A relation between inhibition of protein synthesis and conformation of $5^{\prime}$-phosphorylated 7-methylguanosine derivatives. J. Mol. Biol. 109: 173-183.

Ishida, T., Doi, M., Ueda, H., Inoue, M., and Sheldrick, G.M. 1988. Specific ring stacking interaction on the tryptophan-7-methylguanine system: Comparative crystallographic studies of indole derivatives-7methylguanine base, nucleoside, nucleotide complexes. J. Am. Chem. Soc. 110: 2286-2294.

Kentsis, A., Topisirovic, I., Culjkovic, B., Shao, L., and Borden, K.L. 2004. Ribavirin suppresses eIF4E-mediated oncogenic transformation by physical mimicry of the 7-methyl guanosine mRNA cap. Proc. Natl. Acad. Sci. 101: 18105-18110.

Lazaris-Karatzas, A., Montine, K.S., and Sonenberg, N. 1990. Malignant transformation by a eukaryotic initiation factor subunit that binds to mRNA $5^{\prime}$ cap. Nature 345: 544-547.

Maag, D., Castro, C., Hong, Z., and Cameron, C.E. 2001. Hepatitis C virus RNA-dependent RNA polymerase (NS5B) as a mediator of the antiviral activity of ribavirin. J. Biol. Chem. 276: 4609446098.

Marcotrigiano, J., Gingras, A.C., Sonenberg, N., and Burley, S.K. 1997. Cocrystal structure of the messenger RNA $5^{\prime}$ cap-binding protein (eIF4E) bound to 7-methyl-GDP. Cell 89: 951-961.

Matsuo, H., Li, H., McGuire, A.M., Fletcher, C.M., Gingras, A.C., Sonenberg, N., and Wagner, G. 1997. Structure of translation factor eIF4E bound to m7GDP and interaction with 4E-binding protein. Nat. Struct. Biol. 4: 717-724.

Miller, J.P., Kigwana, L.J., Streeter, D.G., Robins, R.K., Simon, L.N., and Roboz, J. 1977. The relationship between the metabolism of ribavirin and its proposed mechanism of action. Ann. NY Acad. Sci. 284: 211-229.

Muller, W.E., Maidhof, A., Taschner, H., and Zahn, R.K. 1977. Virazole (1- $\beta$-D-ribofuranosyl-1,2,4-triazole-3-carboxamide; a cytostatic agent. Biochem. Pharmacol. 26: 1071-1075.

Niedzwiecka, A., Darzynkiewicz, E., and Stolarski, R. 2004. Thermodynamics of mRNA $5^{\prime}$ cap binding by eukaryotic translation initiation factor eIF4E. Biochemistry 43: 13305-13317.

Novac, O., Guenier, A.S., and Pelletier, J. 2004. Inhibitors of protein synthesis identified by a high throughput multiplexed translation screen. Nucleic Acids Res. 32: 902-915.

Page, T. and Connor, J.D. 1990. The metabolism of ribavirin in erythrocytes and nucleated cells. Int. J. Biochem. 22: 379-383.

Pelletier, J. and Sonenberg, N. 1985. Photochemical cross-linking of cap binding proteins to eucaryotic mRNAs: Effect of mRNA $5^{\prime}$ secondary structure. Mol. Cell. Biol. 5: 3222-3230.

Ruggero, D., Montanaro, L., Ma, L., Xu, W., Londei, P., CordonCardo, C., and Pandolfi, P.P. 2004. The translation factor eIF-4E promotes tumor formation and cooperates with c-Myc in lymphomagenesis. Nat. Med. 10: 484-486.

Sambrook, J. and Russell, D.W. 2001. Molecular cloning. A laboratory manual. Cold Spring Harbor Laboratory Press, Cold Spring Harbor, New York.

Sidwell, R.W., Huffman, J.H., Khare, G.P., Allen, L.B., Witkowski, J.T., and Robins, R.K. 1972. Broad-spectrum antiviral activity of virazole: 1- $\beta$-D-ribofuranosyl-1,2,4-triazole-3-carboxamide. Science 177: 705706.

Sidwell, R.W., Robins, R.K., and Hillyard, I.W. 1979. Ribavirin: An antiviral agent. Pharmacol. Ther. 6: 123-146.

Sonenberg, N. 1981. ATP/Mg++-dependent cross-linking of cap binding proteins to the $5^{\prime}$ end of eukaryotic mRNA. Nucleic Acids Res. 9: 1643-1656.

Sonenberg, N. and Shatkin, A.J. 1977. Reovirus mRNA can be covalently crosslinked via the $5^{\prime}$ cap to proteins in initiation complexes. Proc. Natl. Acad. Sci. 74: 4288-4292. 
Yan et al.

- 1978. Nonspecific effect of m7GMP on protein-RNA interactions. J. Biol. Chem. 253: 6630-6632.

Sonenberg, N., Morgan, M.A., Merrick, W.C., and Shatkin, A.J. 1978. A polypeptide in eukaryotic initiation factors that crosslinks specifically to the $5^{\prime}$-terminal cap in mRNA. Proc. Natl. Acad. Sci. 75: 4843-4847.

Streeter, D.G., Witkowski, J.T., Khare, G.P., Sidwell, R.W., Bauer, R.J., Robins, R.K., and Simon, L.N. 1973. Mechanism of action of 1- $\beta-D-$ ribofuranosyl-1,2,4-triazole-3-carboxamide (Virazole), a new broadspectrum antiviral agent. Proc. Natl. Acad. Sci. 70: 1174-1178.

Svitkin, Y.V. and Sonenberg, N. 2003. Cell-free synthesis of encephalomyocarditis virus. J. Virol. 77: 6551-6555.
2004. An efficient system for cap- and poly(A)-dependent translation in vitro. Methods Mol. Biol. 257: 155-170.

Tahara, S.M., Morgan, M.A., and Shatkin, A.J. 1983. Binding of inosine-substituted mRNA to reticulocyte ribosomes and eukaryotic initiation factors $4 \mathrm{~A}$ and $4 \mathrm{~B}$ requires ATP. J. Biol. Chem. 258: 11350-11353.

Tam, R.C., Lau, J.Y., and Hong, Z. 2001. Mechanisms of action of ribavirin in antiviral therapies. Antivir. Chem. Chemother. 12: 261-272.

Wendel, H.-G., de Stanchina, E., Fridman, J.S., Malina, A., Ray, S., Kogan, S., Cordon-Cardo, C., Pelletier, J., and Lowe, S.W. 2004. Survival signalling by Akt and eIF4E in oncogenesis and cancer therapy. Nature 428: 332-337. 

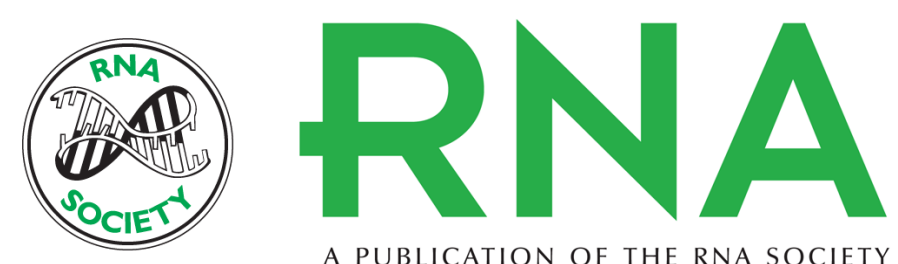

A PUBLICATION OF THE RNA SOCIETY

\section{Ribavirin is not a functional mimic of the 7-methyl guanosine mRNA cap}

YIFEI YAN, YURI SVITKIN, JOSEPH M. LEE, et al.

RNA 2005 11: 1238-1244

References This article cites 43 articles, 17 of which can be accessed free at: http://rnajournal.cshlp.org/content/11/8/1238.full.html\#ref-list-1

\section{License}

Email Alerting Receive free email alerts when new articles cite this article - sign up in the box at the Service top right corner of the article or click here.



